\title{
An Internship Program at a Computer Science Department -Theoretical Foundation and Overall Coordination
}

\author{
Azad Ali and David Smith \\ Indiana University of Pennsylvania, Indiana, PA, USA
}

\section{Azad.ali@iup.edu david.smith@iup.edu}

\begin{abstract}
Internship courses, unlike others, are multi-pronged because they require coordination at different levels. Typically, a faculty member coordinates the communication and implementation at each level to achieve the desired outcomes. We call the position that this faculty holds the "internship coordinator". For the work of the internship coordinator to be successful, he/she may need to synchronize the work of the internship with all parties involved. Failure to coordinate at one level or another may affect the work of other parties involved in completing the internship for the students.

This paper explains the experience of an internship program at the computer science department (COSC) at Indiana University Indiana University of Pennsylvania (IUP). We focus on the work of the internship coordinator for this program and his work to communicate and coordinate to successfully implement the internship experience for the students. We first discuss the theoretical foundation that led to the development of internship programs in academia and then elaborate on the multiple levels of the role of the internship coordinator in completing the internship experience for the students.
\end{abstract}

Keywords: Internship program, internship courses, internship at computer science programs

\section{Introduction}

Internship courses are different than traditional courses that typically teach and lecture in the classroom. While the emphasis of the both type of courses is still on the learning of the students, the delivery method and the mechanism by which the teaching/learning of the internship courses is different than other courses (Arnold, 1998, Gault, Redington, \& Schlager, 2000, Rieks, Greene, Costa, Flaherty, \& Solinger, 2011).

Material published as part of this publication, either on-line or in print, is copyrighted by the Informing Science Institute. Permission to make digital or paper copy of part or all of these works for personal or classroom use is granted without fee provided that the copies are not made or distributed for profit or commercial advantage AND that copies 1) bear this notice in full and 2) give the full citation on the first page. It is permissible to abstract these works so long as credit is given. To copy in all other cases or to republish or to post on a server or to redistribute to lists requires specific permission and payment of a fee. Contact Publisher@InformingScience.org to request redistribution permission.
Typically, a faculty member at a department oversees the planning and coordinating for internship courses. The position of this faculty member is often called the "internship coordinator". For the work of the internship coordinator to be successful, he/she needs to connect with different people and coordinate at different levels. The internship coordinator needs to synchronize the work at all levels to ensure a successful experi- 
ence (Robeck, Pattison, Pate, \& Pattison, 2013). This paper explains the experience of a faculty internship coordinator at the Computer Science department (COSC) at Indiana University of Pennsylvania (IUP). It begins by giving theoretical background literature review about internship courses and the different levels of coordination that are typical involved in an internship course. It then discusses the experience of the internship coordinator at COSC at IUP.

\section{About Internship Courses}

Internship courses are newer in their formats and delivery methods than traditional in-classroom courses. While both types of courses (in-class and internship) share the goal of student learning in attaining their objectives, each use a different methodology to achieve the goal. Traditional courses use the "cognitive" and lecture style of teaching and learning (Arnold, 1998, Furco, 2002). In this style, the transfer of knowledge goes from the teacher to the student (we call this one directional). The view of a professor sitting on a high podium lecturing to the students in the class while the students take notes is one representation of this kind of teaching/learning.

The teaching/learning style of an internship takes a different approach. Some called this approach "Learning by Doing" or "Learning by Experience" (Tooley, 1997) to explain the learning that is taking place during the work of the internship. Gault et al. (2000) call it "structured work experience" to emphasize the structured work that the internship brings and the learning that is taking place through the work.

Internship courses still achieve the goal of student learning - there is still knowledge gained by the students - but the method by which knowledge is gained is different. It is gained through the work experience and whatever goes in the internship process. Nevertheless, given that the transfer of knowledge is not done directly by the teacher, some consider this new format and delivery method as a deviation from the "cognitive" style of traditional classroom teaching (Furco \& Holland, 2004).

Internship courses started initially as a recognition of the need to embed a system that helps students "learning through work" (Champagne, 2006). This transition from "in-class, lecture type learning" to "learning through experience" took a span of years and followed the development of different theories (Casperz, Olaru, \& Smith, 2012). Additionally, this type of learning through experience is not limited to internship courses, instead different course formats are implemented that emphasize learning through experience. Thus we deem an explanation of the development of internship courses is helpful to our discussion.

The remainder of this section explains some of the theories that led to the development of internship and similar courses that implement "learning through work". It then discusses the different format of the courses and sheds light on the development of these courses in the computer science field.

\section{Theories of Learning through Experience}

An internship course entails colleges and businesses working together to provide better learning opportunities for the students. Gault et al. (2000) noted that the idea of colleges and business joining forces to enhance the professional education program dates back to the early 1900s when the University of California developed a program that implemented such partnership. Although this practice may date back to earlier days, most agree that this new pedagogy of "learning through experience" originated at the dawn of the $19^{\text {th }}$ century (Champagne, 2006, Furco, 2004). In particular, the first of these theories was developed by John Dewey and was called "Experiential Education" or "Experiential Learning" (Rieks et al, 2011). Kolb, Boyatzis, and Mainemelis (2001) provided an explanation of the Experiential Learning Theory (ELT) in the following: 
Experiential Learning Theory (ELT) provides a holistic model of the learning process and a multi-linear model of adult development, both of which are consistent with what we know about how people learn, grow, and develop. The theory is called "Experiential Learning" to emphasize the central role that experience plays in the learning process, an emphasis that distinguishes ELT from other learning theories. The term "experiential" is used therefore to differentiate ELT both from cognitive learning theories, which tend to emphasize cognition over affect, and behavioral learning theories that deny any role for subjective experience in the learning process. (p. 2)

Champagne (2006) considers it a new form of pedagogy and credits this pedagogy with promoting relations between universities and their communities. The basic premise of "Experiential Learning" is that as we work on something we will learn from working on it. In other words, the learning is taking place by working on something. Although this is well understood in the industry and in the general practices of life, the use of this "newer" pedagogy changed the ways in which the teaching/learning were taking place in higher education.

The introduction of experiential learning as a pedagogy challenged the previous theories of the role of academic institutions. It challenged the "cognitive style" of "teaching thru lecturing" that was and still is prevalent in academic classrooms (Furco \& Holland, 2002). It also challenged what we called earlier the "one-directional" method of teaching and learning. With the introduction of this new pedagogy, the question that repeats itself is whether or not it is the role of the university to teach the students the practical application (let them learn by doing). Also what other roles universities play in the learning process. However, others answer skepticism about the value of experiential learning courses through the following points:

- The changes in the work environment brought these changes in pedagogy. The work environment is often substantially different than what the students are taught or what they go through in the classroom (Arnold, 1998)

- It is the task of academic systems to prepare the students for the work environment (Mezirow, 1990).

- Although there is no direct transfer of knowledge from the teacher to the students in internship courses, the academic institution takes active role in the learning process. Typically mentoring takes place during internships. Internship programs often coordinate with the internship sites to manage this mentoring and learning process and thus facilitating the learning process (Trede, Mcewen, \& Sheehan, 2013)

- Experiential learning complements and enhances the learning that takes place in the classroom (Toncar \& Cudmore, 2000)

\section{Classification of Experiential Learning Courses}

Gault et al. (2000) explained about three types of experiential learning courses taught in higher education: cooperative extensions, cooperative education (or co-op), and internship. According to Gault et al. "Cooperative extension programs refer to state-sponsored agricultural work experiences and are therefore not included in this study (p. 46)". However, the other types of courses are still being used and taught at colleges and universities.

In regards to cooperative education courses, Theil and Hartley (1997) noted that students used to take these courses to finance their education. Gault et al. (2000) took an example of teacher edu- 
cation to explain about internships where students concurrently take courses and enroll in internship and where teaching practice is required for state certification.

In addition to the above, internship courses can be classified differently according to different criteria. Some of the criteria that classify internship include the following:

- Number of credits taken and number of hours to work for each

- Span of the internship in weeks, months, semesters or longer period of time

- Part time or full time - depending on hours worked

- Payment (paid or unpaid internships).

Each of these categories from the above presents different challenges to the university. Take, for example, the length of time to take internship course. If the course lasts more than one semester, then the university may need to establish different mechanism for temporarily grading the work before the internship is completed. Another challenge may be presented in the format of courses (such as part-time) because the university may have to associate the number of internship hours for each credit to be taken.

Deciding on an internship to be paid or unpaid may seem on the surface not problematic. After all, students in general are happy to gain the internship experience which may give them a foot in the door for their first job. But this is not always the case. Svacina (2013) explained about this: "At the surface unpaid internships just appear to be a simple solution for students to gain professional experience and build their resumes. However, unpaid internships present a number of legal concerns; in particular, the exploitation of student workers" (p. 78). Additionally there is evidence that paid internships increase the likelihood of obtaining employment upon graduation. Research from the National Association of Colleges and Employers (NACE) (2013) indicates that the likelihood is twice that of unpaid internship, which is marginally better that no internship.

\section{Experiential Learning at Computer Science Programs}

Similar to the other programs, computer science programs noted the necessity of adding experiential learning courses into their curriculum. The computer science programs (and all information technology programs) in general faced criticism in terms of their coverage. Among the criticism that faced IT explained that IT programs do not teach and what is required in the industry. ScottBracey (2013), for example, called it the "skill gap" and pointed particularly to the absence of teaching important skills needed for work in the IT programs. McGill (2009), on the other hand, called it the "expectation gap" referring to the difference between what is considered important skills by the industry and those taught in academia. Others criticized the examples given in computer science courses because they do not resemble to what is practiced in the industry at all (Westfall, 2001). This came in reference to displaying the message of "Hello World" that is used as an example to teach students to write a first program in computer programming courses.

Whether or not to teach practical experience in IT courses has been subject of discussion at different levels. The question that is debated often in IT courses is how much of teaching theory versus how much of practical application does a faculty allow in his/her courses. Ali and Mensch (2008) call this the teaching of theory (concepts) versus the teaching of application (or hand-on instructions). Ali and Mensch noted that a balanced approach between the teachings of the two is essential to IT education. Denning (2001), on the other hand, noted that the balance of coverage between application and concepts in IT involves the following.

Learning the professional practices of a specialty of information technology is every bit as important as learning the intellectual core of computing. The mark of a well-educated professional will be a balance of the two. The current academic 
inclination to disdain skill-specific training does not fit a profession. The education of computing professionals must count for practices as well as descriptive knowledge. It must include training as well as general education. (p. 263)

Although the traditional emphasis was on teaching concepts in IT courses, the most recent move calls for allowing more of the teaching of practical applications in these courses. This is represented by the increasing offering of IT courses in computer labs. In these labs, faculty are typically able to teach concepts while at the same time being able to supervise the hands-on the work on the practical applications. This is also represented in offering more internship course in IT programs in general and in computer science programs in particular.

\section{Coordinating an Internship Program}

The role of internship coordinator can be undertaken by a faculty member in each department. It can also be centralized through the career service department. In either case, the internship coordinator has distinct role to play with different participants in the internship process. Theil and Hartley (1997) explained four of these roles for the internship coordinators: develop sites, recruit students, monitor the internship, and assess the results. Arnold (1998) explained that there are three different participants that the internship coordinator has to deal with in internship courses: the student, the firm, and the university. Figure1 shows a depiction of the internship work as coordinated by the internship coordinator.

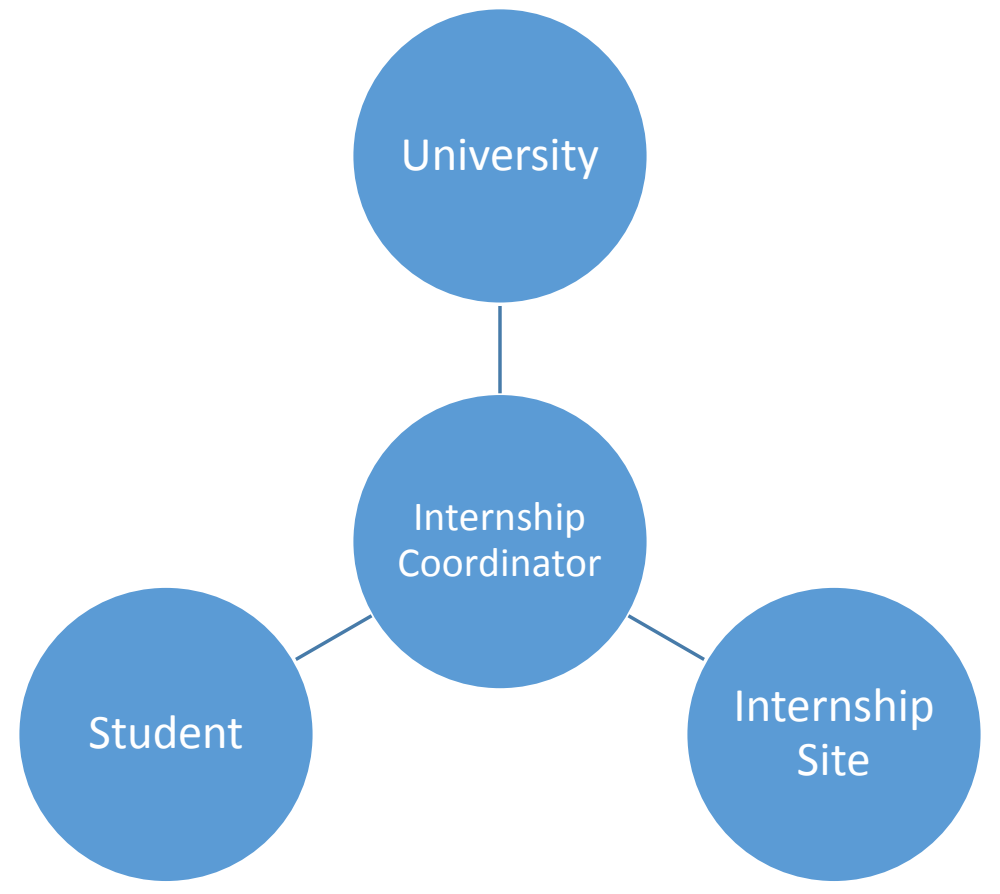

Figure 1 - Coordination of Internship

The internship coordinator deals with the three participants differently. Different procedures and practices are followed with each of the three participants in order to assure the completion of the internship experience. The remainder of this section explains about the work of each of the participants in the internship experience and the role of the internship coordinator in synchronizing their work. 


\section{The University}

The university is the entity that offers the internship course and provides the mechanism by which the teaching/learning process is to be implemented in the internship course. Given that the internship courses are unlike traditional courses, this may require following different steps and university regulations to gain authority to offer these courses (Robeck, 2013). These steps may entail different procedure or to what is called "institutionalizing" of experiential learning courses (Furco \& Holland, 2004; Homkes \& Taylor, 2006).

The internship coordinator may have to take into considerations different factors in order to offer an internship course and still follow university regulations. Some of what is taken into consideration when offering internship courses include the following (Svacina, 2013; Tooley, 1997; Van Hoof, 1999):

- Decide on number of credits to take for the course

- Number of hours to work for each internship

- Span of the course in weeks, months or semesters.

- Eligibility procedures for approving internship sites

For some of the above points to be implemented, the university may need to establish additional procedures for internship courses. Take for example the length of the internship course. If takes more than one semester to complete, the university may need to set (institutionalize) procedures to allow for interim grade until the course is fully completed

Another example is the selection of the internship sites. Universities may need to set their own criteria for selecting a site. Thiel and Hartley (1997) explained that the absence of clear criteria may lead to results that are counterproductive to the students and to the university. They gave an example of how they relied on a student to find an internship site; later they found out that the internship site was a Dairy Queen site where the student was helping his mother to sell ice cream.

\section{The Internship Site}

The internship site is where the students goes to work for his/her practical application. The role of the internship coordinator starts before taking the internship course, and it extends through the internship and sometime afterwards.

Before starting the internship, the internship coordinator may have to secure internship locations for the students to work at for their internships. Finding internship sites may need research and follow-ups by the internship coordinator. It also may require knowledge of the market demand for their program. Smith and Ali (2014) suggested that one way to gain knowledge of the market demand is to repeatedly search different job advertisement databases and to keep a record of them for comparison and analysis. Huang, Kvasny, Joshi, Trauth, \& Mahar (2009) explained numerous advantages can be gained by faculty from monitoring the market demand. This continuous monitoring helps the faculty target and find specific sites that look for temporary work similar to what is offered in internship courses.

\section{The Student}

Arnold (1998) notes one of the major disappointments of internship courses is the lack of fit between internship requirements and the students' background. This may be due primarily to the lack of academic preparation for the students. But it may also be due to unrealistic expectations of the work site on the part of the student. In either case, this stresses that the role of the internship coordinator with the student starts before the internship, it continues while the internship is going on, and it extends until after the completion of the internship. 
Before beginning the internship, the coordinator needs to prepare the students for the internship (Theil \& Hartely, 1997). This includes completion of pre-requisites needed to ensure sufficient background for success at the internship site together with an approval process. The coordinator need to provide this information to the students and provide advice in preparing the student to meet the requirements. One other issue includes setting the student expectations. One study found that the majority of students are disappointed to learn the difference between what they expected and what they saw during their internship (Arnold, 1998). The disappointment is due to the lack of preparation of students' hard skills - which they may not have been taught correctly. It is also due to issues with the development of soft skills that are essential for all individuals entering the job market (Litecky, Arnett, \& Prabhakar 2004).

During the internship and while the student is working at the site the internship coordinator keeps open dialogue with the student regarding his/her progress. This may also include getting feedback about problems that may arise and dealing with others issues regarding managing the internship.

After completing the internship, the coordinator has the responsibility of completing the evaluation of the student's work. Within procedures for evaluating the work of the students, the coordinator may use techniques that solidify the learning experience for the student. Mezirow (1990) suggested "critical reflection" as one way to solidify learning because such reflection "triggers transformative learning." In all cases, follow up with the students regarding their views of the internship experience will help the students themselves and will help future internships as well.

\section{The Internship Program at COSC}

The Computer Science department (COSC) at Indiana University of Pennsylvania has been offering an internship courses for many years. It started in 1971 after the realization of the importance of practical experience for computer science graduates. Today the internship is considered to be one of two options for the student to complete the practicum requirement of the degree program. The other option is a course that simulates a company on campus.

In order to meet the practicum requirement, 12 internship credits must be completed. Traditionally this involves a duration of six months in which the student starts in January and continues to mid-summer (or beyond) or starts in the first part of the summer and continues through the fall. Due to the increase in popularity of internships many companies began offering structured internship programs over the summer. To accommodate these programs, the 12 credit internship can be split into two semesters with six credits each completed in consecutive summers.

Most of the internship courses at COSC are paid internships. They vary in location at different states including Pennsylvania, New York, California, Ohio, and Illinois, and in the type of company. Some students may work for banks and financial institutions. Some may work for manufacturing firms. Still others may work for government sectors. Furthermore, the type of work varies according to student interest. Many involve traditional core of software development. Some involve tasks on the periphery of software development including maintenance, quality assurance, or analysis. Others involve diverse areas such as database administration, digital forensics, information assurance administration, network administration, and computer science research.

\section{The University}

The university's career center provides assistance to students in locating internship sites and in preparation to successfully complete the employment process. Mock interviews provide practice and coaching in the interview process. Resume review and critiques assist the student in preparing the resumes. Career fairs both on and off campus enable the student to directly meet the company recruiters. Lastly, a job listing and resume database enable connections between students and potential sites. 
The university has supported the internship program as defined by the computer science department. A six month internships extends beyond the boundaries of semester. Grading policies of a "Late" grade accommodate this extension and enable completion of academic components (see the section on the student below) at a time into the next semester. The late grade is replaced with the student's final grade upon final submission of the internship report and other materials. Furthermore the support of a 12 credit internship enables the student to be a full time employee at the internship site while at the same time a full time student. In addition to the internship, a student can take a distance education class that ensures the student maintains progression through his or her academic program.

\section{The Internship Site}

The internship site provides meaningful assignments and the day to day supervision of the student. The sites understand that the students have limited experience and are considered to be trainees. At most sites students are part of a team that includes veteran developers who are readily available to assist when needed. Furthermore the manager, project lead, or one of the employees in the site is often assigned to mentor the student. Quickly the students become productive members of their respective teams. The assigned tasks introduce the student to new skills not covered in school and/or provide practice in the skills acquired in class to far greater depth. The site has resources for the tasks at hand both in equipment and software tools, all of which may be new to the student.

\section{The Student}

At the internship site students are quickly engaged in the assigned project work. They learn from mentors and other members of the team the technologies employed at the site. Furthermore, students gain soft skills in communication and team work. Within a few short weeks the students can be working on real projects that contribute to the mission of the company. Often their work is released into production providing meaning to the work experience.

In order to earn college credit, the student must complete the academic component of the internship. This begins with preparing the resume and other documents to seek employment and continues into the semester following completion of work at the internship site. The student must attend a meeting prior to the start of the internship at the site, meet with the faculty individually two times at the site and two times on campus, maintain daily and project logs, compile a documentation portfolio, prepare and give a presentation to future interns on campus, and turn in a final report of the internship experience.

\section{Summary and Suggestion for Future Research}

This paper explained about the internship programs in general and focused on internship courses taught the computer science programs. It selected a course at the Computer Science program (COSC) department at Indiana University of Pennsylvania (IUP) and focused on their experience in planning and completing internship courses. It explained about the role of the internet coordinator at the COSC program and provided theoretical background that led to the development of internship courses (and similar experiential learning courses).

This is our first paper regarding the internship experience at the COSC program and we are planning to follow up with more studies. Our next paper is going to be about preparing students for the internship experience. Our plan is to research and write about the steps that are typically followed by the faculty coordinator to prepare the students for internship. We will also focus the preparation steps followed at the COSC program. Thus preparing the students for the internship experience will be the focus of our next study in this topic. 


\section{References}

Ali, A., \& Mensch, S. (2008). Issues and challenges in selecting content for web design courses. Journal of Issues in Informing Science and Information Technology, 5, 209-231.

Arnold, M. J. (1998). An empirical taxonomy of student expectations of marketing internship programs. Journal of Marketing Education, 20(2), 94-102.

Champagne, N. (2006). Service learning: Its origin, evolution, and connection to health education. American Journal of Health Education 37(2), 97-102.

Caspersz, D., Olaru, D., \& Smith, L. (2012). Striving for definitional clarity: What is service learning?. Teaching and Learning Forum, 2\&3, 1-16.

Denning, R. J. (2001). Computing the profession: Practical experiences for undergraduate computer networking students. Consortium for Computing Sciences in Colleges, pp. $261-270$.

Furco, A. (2002). Self-assessment rubric for the institutionalization of service-learning in higher education. Campus Compact Engaged Scholar Service-Learning Research \& Development Center, University of California.

Furco, A., \& Holland, B. (2004). Institutionalizing service-learning in higher education: Issues and strategies for chief academic officers. In M. Langseth \& S. Dillon (Eds.), Public work and the academy: An academic administrator's guide to civic engagement and service learning (pp. 23-39). Bolton, MA: Anker Publishing Company.

Gault, J., Redington, J., \& Schlager, T. (2000). Undergraduate business internships and career success: Are they related? Journal of marketing education, 22(1), 45-53.

Hatcher, J. A., Bringle, R. G., \& Muthiah, R. (2004). Designing effective reflection: What matters to service-learning? Michigan Journal of Community Service Learning, 11(1), 38-46.

Homkes, R., \& Taylor, K. (2006).Institutionalizing service learning. Proceedings of the 9th International Conference on Engineering Education, T3E-20 - T3E-23.

Huang, H., Kvasny, L., Joshi, K. D., Trauth, E. M., \& Mahar, J. (2009, May). Synthesizing IT job skills identified in academic studies, practitioner publications and job ads. In Proceedings of the Special Interest Group on Management Information System's 47th Annual Conference on Computer Personnel Research (pp. 121-128). ACM.

Kolb, D. A., Boyatzis, R. E., \& Mainemelis, C. (2001). Experiential learning theory: Previous research and new directions. Perspectives on thinking, learning, and cognitive styles, 1, 227-247.

Litecky, C. R., Arnett, K. P., \& Prabhakar, B. (2004). The paradox of soft skills versus technical skills in IS hiring. Journal of Computer Information Systems, 45(1).

McGill, M. M. (2009, April). Defining the expectation gap: A comparison of industry needs and existing game development curriculum. In Proceedings of the 4th International Conference on Foundations of Digital Games (pp. 129-136). ACM.

Mezirow, J. (1990). How critical reflection triggers transformative learning. In J. Mezirow, Fostering critical reflection in adulthood (pp. 1-20). Jossey-Bass

National Association of Colleges and Employers. (2013, May 29). Class of 2013: Paid interns outpace unpaid peers in job offers, salaries. Retrieved from https://www.naceweb.org/s05292013/paid-unpaidinterns-job-offer.aspx

Rieks, A. R., Greene, D. T., Costa, M. R., Flaherty, M. G., \& Solinger, C. (2011, February). Bridging theory and practice: Connecting coursework to internships in LIS programs. In Proceedings of the 2011 iConference (pp. 763-764). ACM.

Robeck, J., Pattison, A., Pate, S., \& Pattison, J. (2013). The Impact of fashion merchandising internships on careers. Journal of Cooperative Education \& Internships, 47(1). 
Scott-Bracey, P. (2013). Analyzing internet job advertisements to compare IT employer soft skill demand versus undergraduate IT program curriculum programs in Texas. Retrieved 10/15/2013 from http://www.editlib.org/noaccess/38669

Smith, D., \& Ali, A. (2014). Analyzing computer programming job trend using web data mining. Issues in Informing Science and Information Technology, 11, 203-214.

Svacina, L. S. (2012). A review of research on unpaid internship legal issues: Implications for career services professionals. Journal of Cooperative Education and Internships, 46, 77-87.

Sanderson, P. (2003). Where's (The) Computer Science in Service Learning? Consortium for Computing Sciences in Colleges, retrieved February 10, 2008 from ACM digital Library http://www.acm.org/dl

Trede, F., Sheehan, D., \& Mcewen, C. (2013). Investigating what constitutes an effective workplace learning environment: A scoping review of the role physical and material elements play in student learning. Journal of Cooperative Education \& Internships, 47(1), 94-105.

Toncar, M. F., \& Cudmore, B. V. (2000). The overseas internship experience. Journal of Marketing Education, 22(1), 54-63.

Tooley, J. A. (1997). Working for credit. U.S. News \& World Report, 123(19), 76.

Thiel, G. R., \& Hartley, N. T. (1997). Cooperative education: A natural synergy between business and academia. SAM Advanced Management Journal (07497075), 62(3), 19.

Van Hoof, H. B. (1999). The international student experience: A US industry perspective. Journal of Studies in International Education, 3(2), 57-71.

Westfall, R. (2001). Technical opinion: Hello, world considered harmful. Communications of the ACM, 44(10), 129-130.

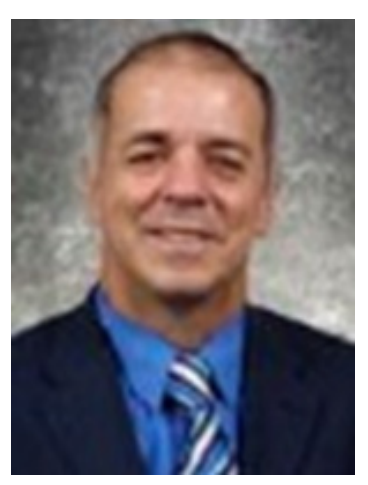

\section{Biographies}

Azad Ali, D.Sc., Professor of Information Technology at Eberly College of Business - Indiana University of Pennsylvania - has 30 years of combined experience in areas of financial and information systems. He holds a bachelor degree in Business Administration from the University of Baghdad, an M.B. A. from Indiana University of Pennsylvania, an M.P.A. from the University of Pittsburgh, and a Doctorate of Science in Communications and Information Systems from Robert Morris University. Dr. Ali's research interests include service learning projects, web design tools, dealing with isolation in doctoral programs, and curriculum.

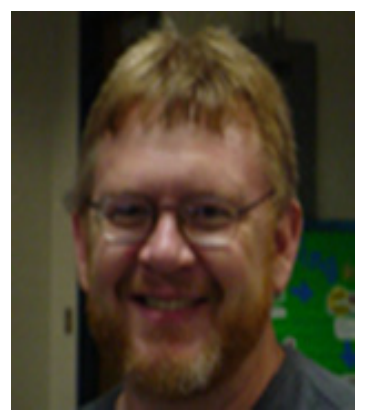

David T. Smith, Ph.D., Associate Professor of Computer Science - Indiana University of Pennsylvania - has 13 years experience in academia and 21 years of industry experience in database systems, computer language development, and other systems programming. He holds a bachelor degree in Physics and Mathematics Education from Indiana University of Pennsylvania, an M.S. in Computer Science from University of Central Florida, and a Ph.D. in Computer Science from Nova Southeastern University. Dr. Smith is active in consultancy and has research interests in artificial intelligence, distributed object computing, data mining, and software engineering. 